\title{
Pengembangan Komik Edukatif tentang Dampak Pacaran pada Remaja
}

\author{
Palasara Brahmani Laras \\ Program Studi Bimbingan dan Konseling, Fakultas Keguruan dan Ilmu Pendidikan, \\ Universitas Mercu Buana Yogyakarta \\ palasara@mercubuana-yogya.ac.id
}

\begin{abstract}
Abstrak
Penelitian ini bertujuan untuk menghasilkan media komik edukatif tentang dampak pacaran pada remaja kelas 8 Sekolah Menengah Pertama. Metode penelitian yang digunakan adalah metode penelitian pengembangan $(\mathrm{RnD})$. Prosedur penelitian yang dilakukan dalam penelitian ini 1) potensi dan masalah, 2) pengumpulan data, 3) desain produk, 4) validasi desain, 5) revisi desain, 6) uji coba produk, 7) revisi produk, 8) uji coba pemakaian, 9) revisi produk, 10) produksi masal. Komik edukatif dikembangan sebagai salah satu alternatif media dalam proses layanan Bimbingan dan Konseling. Hasil uji validasi desain meliputi uji validasi ahli materi sebesar 78,12\%, hasil uji validasi ahli media sebesar $91,18 \%$, dan hasil uji validasi ahli layanan bimbingan dan konseling sebesar $100 \%$. Tahap selanjutnya adalah tahap uji coba lapangan utama dengan subjek 10 siswa dengan hasil sebesar 86,67\%, dan tahap uji coba lapangan operasional dengan subjek 30 siswa sebesar 89,35\%. Berdasarkan hasil uji penilaian tersebut komik edukatif ini dapat dikategorikan "sangat baik" dengan rentang nilai 75-100 yang menjadi kriteria patokan dalam penilaian pengembangan ini. Dengan demikian hasil temuan komik edukatif tentang dampak pacaran pada remaja yang telah diuji cobakan pada siswa kelas 8 Sekolah Menengah Pertama dikategorikan layak digunakan sebagai media dalam pelaksanaan layanan Bimbingan dan Konseling.
\end{abstract}

Kata Kunci: Komik Edukatif; Layanan Informasi; Pacaran Remaja.

\begin{abstract}
This research aims to deliver educative comic media about the impact of teenagers dating on $8^{\text {th }}$ grade junior high school. The research method was development research method $(R n D)$. The research procedures in this research were 1) potential and problems, 2) data collection, 3) product design, 4) design validation, 5) design revisions, 6) product trials, 7) product revisions, 8) usage trials, 9) product revision, 10) mass production. Educative comic was developed as an alternative media in the process of guidance and counseling services. The results of the design validation test were carried out by three experts with material expert validation test result of $78.12 \%$, media expert validation test result of $91.18 \%$, and validation testing of guidance and counseling services test result of $100 \%$. The next steps were main trial stage with the
\end{abstract}


subjects of 10 students with a result of $86.67 \%$, and operational trial with the subject of 30 students with a result of $89.35 \%$. Based on the results of the assessment educative comic test can be categorized as "very good" with value range of 75-100 which is the main criteria in evaluating this development. Thus, the findings of educative comic about the impact of teenagers dating have been tested on $8^{\text {th }}$ grade junior high school was appropriate categorized to be used as a medium in the implementation of guidance and counseling services.

Keywords: Educative Comic; Information Services; Teenagers Dating.

\section{PENDAHULUAN}

Masa remaja merupakan suatu tahap kehidupan yang bersifat peralihan. Masa remaja adalah masa yang rawan oleh pengaruh-pengaruh negatif, seperti narkoba, kriminal, dan kejahatan seks. Pergaulan yang menuju pada seks bebas dapat membahayakan tumbuh kembang remaja, karena bisa terjangkit berbagai penyakit kelamin terutama HIV/AIDS. Penyakit ini sudah banyak terjadi diberbagai negara dunia termasuk Indonesia. Menurut Maria dikutip dari (http://www.tempo.co/read/news/2012/06/06/174408718/KPAIPacaran-Pertama-An ak-Indonesia-Umur-12-Tahun)"seks bebas ini membuat angka penderita HIV/AIDS dikalangan remaja meningkat tajam. Ada peningkatan 700 persen dari jumlah antara tahun 2004 hingga 2010, dari awal 154 kasus menjadi 1.119 kasus".

Perubahanhormonal pada fase remaja tidak hanya menyebabkan perubahan bentuk fisik, tetapi perubahan emosional, baik remaja laki-laki maupun perempuan. Perubahan fisik menyebabkan bentuk tubuh mereka menjadi lebih matang dari segi reproduksi, sedangkan perubahan emosional menyebabkan tumbuh perasaan saling tertarik, rindu, cemburu, sedih, gembira, cinta dimiliki, dan ingin memiliki. Perasaan-perasaan ini mendorong remaja untuk saling terpikat dan memikat lawan jenis. Berbagai daya dan upaya remaja tampilkan untuk melontarkan daya tarik. Ketertarikan terhadap lawan jenis yang muncul dalam bentuk senang bergaul dengan lawan jenis dan sampai pada berpacaran.

Maslow (dalam Alwisol 2005, hlm. 259) mengemukakan bahwa pacaran: Termasuk dalam jenis cinta Deficiency atau D-love yaitu kebutuhan cinta karena kekurangan, orang yang mencintai sesuatu yang tidak dimiliki, seperti harga diri, seks, atau seseorang yang membuat diri menjadi tidak sendirian. Sedangkan Al-Adawiyah (2010, hlm. 29) memaparkan pacaran sebagai cara mengekspresikan perasaan suka pada lawan jenis, dan ditindak lanjuti dengan perilaku-perilaku yang dianggap romantis dan kemudian publik memberikan pengakuan jika A pacaran dengan B, dan A pacar dari B. Pacaran ini biasa mulai muncul pada masa awal pubertas, perubahan hormon dan fisik yang memacu membuat individu mulai tertarik pada lawan jenis" (Aden, 2010, hlm. 83).

Pacaran telah menjadi fenomena yang banyak digandrungi oleh remaja saat ini, Berdasarkan hasil survei Kepala Dinas Kesehatan Kabupaten Sintang Kalimantan Barat, dikutip dari (http://theglobejournal.com/kesehatan/survey-perilaku-seks-60persen-abglaku kan-aborsi/index.php) Pacaran merupakan awal dari perilaku seks remaja dikatakan 
oleh Marcus bahwa selama pacaran minimal sudah melakukan petting, 6 persen remaja putri yang pacaran sudah petting, 19 persen untuk remaja laki-laki. Selain itu remaja yang pacaran sudah melakukan hubungan seksual, satu persen dari remaja yang melakukan hubungan seksual hamil, dan 60 persen berakhir dengan aborsi.

Menurut Maria Ulfah Anshor, Ketua (KPAI) dikutip dari (http://www.tempo.co /read/news/2012/06/06/174408718/KPAIPacaran-Pertama-Anak-Indonesia-Umur-12-Tah un) mengatakan bahwa mulai berbagai adegan yang mengarah pada urusan seksual ini tidak lepas dari aktivitas pacaran dini. Banyak remaja Indonesia sudah melakukan pacaran kala usia mereka 12 tahun. Usia ini adalah usia rata-rata remaja saat ini dalam melakukan pacaran. Anak kelas enam SD saat ini, sudah tidak segan lagi memadu kasih. terlebih lagi, perilaku tidak senonoh dilakukan para remaja yang berpacaran ini kala bertemu dengan pasangannya. Berdasarkan data survey tersebut sekitar 92\% remaja yang berpacaran, saling berpegangan tangan. Ada $82 \%$ yang saling berciuman. Dan, $63 \%$ remaja yang berpacaran, tidak malu untuk saling meraba (petting) bagian tubuh kekasih yang itu bersifat tabu untuk dilakukan.

Berdasarkan data dari Badan Koordinasi Keluarga Berencana Nasional (BKKBN) pada tahun 2010 menunjukkan, 51\% remaja di Jabodetabek telah melakukan seks pra nikah, di Surabaya mencapai 54\%, di Medan 52\%, di Bandung 47\% dan Yogyakarta 37\%. Data yang dikumpulkan BKKBN selama kurun waktu 2010 saja. Dari kasus perzinaan yang dilakukan para remaja putri tersebut yang paling dahsyat di Yogyakarta. Pihaknya menemukan dari hasil penelitian di Yogyakarta kurun waktu 2010 setidaknya tercatat sebanyak 37\% dari 1160 mahasiswi di kota gudeg tersebut menerima gelar MBA (marriage by accident) alias menikah akibat hamil sebelum nikah.

Dampak pacaran yang terjadi membuat para remaja sangat kurang memperdulikan tentang norma, nilai-nilai agama, dan adat istiadat. Pacaran pada masa remaja sekarang membawa remaja kepada perbuatan seperti perzinahan, melatih kemunafikan, menjadikan seseorang banyak berkhayal, sehingga mengurangi produktivitas, menjadikan hidup boros, melemahkan daya kreatifitas dan menyulitkan konsentrasi dalam belajar, terhambatnya dalam proses penyelesaian studi, memicu terjadinya pertengkaran dan pembunuhan, hanya karena berebut pacar. Semua terjadi karena pikiran hanya tertuju kepada pacar. Hal ini jika dibiarkan terus menerus akan berdampak pada kualitas SDM pada masa yang akan datang.

Remaja saat ini lebih berani untuk melakukan apapun demi pacar memberikan apa yang disukai pasangan berupa materi, waktu bahkan lebih gawat lagi memberikan kehormatan dan kesucian demi kekasih yang dicintai tanpa berfikir panjang dengan apa yang dilakukan. Gaya pacaran remaja masa kini tidak lagi konvensional dengan cara mengirim salam, melihat dari jauh, atau bersurat-suratan. Hasil penelitian Rita Damayanti (dalam Farida, dkk 2009, hlm. 2) menemukan fakta bahwa "gaya pacaran remaja saat ini sangat melewati batas norma yang selama ini dianut yaitu berupa perilaku yang dianggap tabu seperti berciuman bibir, meraba-raba dada, saling menggesekan alat kelamin dan hingga berhubungan seks (seks pranikah)". 
Menurut Rony Setiawan dan Siti Nurhidayah (2008) dalam penelitiannya menemukan ada hubungan yang signifikan antara perilaku pacaran dengan perilaku seksual pra nikah pada remaja Sekolah Menengah Atas dan faktor-faktor yang mempengaruhi perilaku seksual pranikah antara lain waktu usia dari pubertas sampai menikah diperpanjang, ada kesempatan untuk melakukan perilaku seksual pranikah, paparan media masa tentang seks, komunikasi yang kurang efektif dengan orang tua, mudahnya menemukan alat kontrasepsi yang tersedia bebas dan kurang pemahaman etika moral dan agama.

Media masa yang berkembang semakin pesat membuat akses informasi semakin cepat dan mudah termasuk informasi seksual tanpa batas, tidak sedikit informasi yang diperoleh remaja disalahartikan sehingga menimbulkan berbagai perilaku menyimpang yang berakibat tidak saja merugikan remaja itu sendiri, tetapi juga dapat merugikan orang lain, seperti melakukan hubungan seks dengan pacar tanpa memperhitungkan akibat yang timbul, yaitu kehamilan, penyakit menular seksual, mencoreng nama baik dan kehormatan keluarga. Remaja harus dapat memfilterisasikan diri dalam menerima informasi dan memperkuat keimanan agar terhindar dari hal-hal yang merusak diri remaja.

Remaja harus bisa berkembang dengan baik sesuai dengan tugas perkembangan masing-masing, salah satu tugas perkembangan yang harus dicapai yaitu remaja mampu mencapai hubungan yang lebih matang dengan teman lawan jenis antara laki-laki dan perempuan didasari dengan kemampuan bertindak secara bertanggung jawab dan mengembangkan sistem nilai dan etika sebagai pegangan bertindak.

Remaja dapat menghindari dampak pacaran apabila dalam diri remaja tertanam pemahaman yang bermakna tentang dampak pacaran dan remaja mampu mempunyai keyakinan untuk menghindari perbuatan yang negatif dan mempunyai kekuatan untuk melakukan perilaku positif, meskipun tantangan yang dihadapi relatif besar. Peserta didik perlu diberikan pengetahuan dan pemahaman tentang dampak dari pacaran sehingga peserta didik memahami, mampu mengendalikan diri dalam bergaul sesuai dengan nilai moral, etika dan mengganti hubungan pacaran dengan bersahabat, untuk itu agar materi mengenai dampak pacaran dapat dipahami dengan baik oleh peserta didik, materi perlu dikemas dengan media yang sesuai dengan keadaan dan kondisi di lapangan.

Peranan media layanan Bimbingan dan Konseling tidak dapat diabaikan. Media sangat penting dan bisa menjadi pilihan dalam melaksanakan proses layanan Bimbingan dan Konseling, namun kenyatan yang ada pemanfaatan media layanan Bimbingan dan Konseling masih kurang mendapat perhatian dari guru Bimbingan dan Konseling dalam bentuk pemberian layanan masih konvensional dan terbatas. Layanan bimbingan menjadi monoton dan kurang mendapat perhatian peserta didik, sehingga membuat peserta didik merasa jenuh dalam mengikuti layanan Bimbingan dan Konseling di sekolah. Perlu kreatifitas dan inovatif guru dalam memberikan bahan ajar dan mengembangkan media agar peserta didik dapat mengikuti pelajaran atau bimbingan dengan baik.

Farida Harahab, Dkk (2009) mengemukakan bahwa komik edukasi sebagai media bimbingan pribadi sosial bagi guru Bimbingan dan Konseling di DIY dapat digunakan 
untuk mengingkatkan efikasi diri siswa SMA terhadap perilaku seksual beresiko. Sedangkan Elis Mediawati (2011) dalam penelitiannya menemukan media pembelajaran dengan menggunakan komik edukatif dapat meingkatkan hasil belajar mahasiswa akutansi.

Komik edukatif sebagai media layanan Bimbingan dan Konseling dapat digunakan untuk menyampaikan informasi tentang dampak pacaran pada remaja. Susiani (2006, hlm. 1) mendefinisikan komik sebagai tampilan gambar-gambar dan lambang-lambang yang berurutan. Gambar tersebut merupakan bagian seni visual yang dapat dilihat oleh mata, memberikan cerita yang berurutan. Komik terdiri dari gambar-gambar yang bercerita, sehingga komik bisa disajikan tanpa deretan kalimat yang panjang. Sedangkan menurut Mc Cloud (dalam Gumelar 2011, hlm. 6) mendefinisikan komik sebagai gambar yang berjajar dalam urutan yang disengaja, dimaksudkan untuk menyampaikan sebuah informasi atau menghasilkan respon estetik dari pembaca. Media komik dapat memberikan informasi, menciptakan minat para peserta didik, mengaktifkan proses belajar dan mampu menghasilkan respon dari pembaca atau peserta didik.

Selama ini kenyataan yang ada menunjukan masih kurangnya media bergambar yang cukup menarik untuk menjelaskan berbagai isu sensitif tentang diri remaja, dan sebagai perantara karena para guru masih banyak yang malu untuk menjelaskan materimateri yang menurut norma yang dianut guru cukup tabu untuk dibicarakan. Syarifah, Dkk: 1997; Safrina, 2000; Dawam, 2003; (dalam Farida, Dkk; 2009, hlm. 6) "simulasi media bergambar dapat merangsang siswa mendiskusikan berbagai pengalaman penting yang mungkin terjadi pada diri remaja dan dapat mendiskusikan dengan teman-teman dan guru secara terbuka".

Komik edukatif sebagai alat bantu atau media penyampaian layanan informasi tentang pemahaman dampak pacaran pada remaja, sangat berpotensi dan belum banyak digali, bahkan, belum ada terutama untuk menyampaikan materi pendidikan mengenai dampak pacaran yang terkait dengan Bimbingan dan Konseling bagi siswa SMP, komik edukatif yang dikemas dengan cerita yang menarik sesuai dengan aktifitas pergaulan remaja di sekolah, diharapkan cerita dalam komik ini mampu membuat peserta didik yang membaca dapat menginstropeksi dan merenungkan informasi yang diperoleh dari hasil membaca komik edukatif ini sebagai acuan dalam bertindak. Dengan cerita dan gambar yang menarik diharapkan antusias peserta didik akan bertambah dalam mengikuti layanan Bimbingan dan Konseling di sekolah. Berdasarkan pemaparan di atas penelitian ini "Pengembangan Komik Edukatif Tentang Dampak Pacaran pada Remaja SMP”.

\section{METODE PENELITIAN}

\section{Pendekatan Penelitian}

Penelitian ini menggunakan pendekatan penelitian pengembangan (Resesrch and Development). Borg and Gall (dalam Sugiyono, 2008, hlm. 4) menyatakan bahwa penelitian dan pengembangan (Research and Development/R\&D) merupakan metode penelitian yang digunakan untuk mengembangkan atau memvalidasi produk-produk yang digunakan dalam pendidikan dan pembelajaran. Produk yang dimaksud dalam penelitian 
ini adalah komik edukatif tentang dampak pacaran pada remaja yang digunakan sebagai media layanan informasi Bimbingan dan Konseling, bagi siswa SMP.

\section{Model Pengembangan}

Ada tiga macam model pengembangan, model tersebut akan dipakai sebagai acuan dalam penelitian pengembangan ini. Tim Puslitjaknov (2008, hlm. 8) tiga macam model pengembangan yaitu meliputi model prosedural, model konseptual, dan model teoritik. Model prosedural adalah model yang bersifat deskriptif, yaitu dengan menggariskan langkah-langkah yang harus diikuti untuk menghasilkan produk. Model konseptual adalah model yang bersifat analaitis yang memberikan komponen-komponen produk yang akan dikembangkan serta keterkaitan antar komponen, dan model teoritik adalah model yang menunjukkan hubungan perubahan antar peristiwa.

Penelitian pengembangan komik edukatif tantang dampak pacaran pada remaja SMP ini menggunakan model pengembangan prosedural yang bersifat deskriptif, yaitu menggariskan langkah-langkah yang harus diikuti untuk menghasilkan produk. Produk yang dimaksud pada model pengembangan prosedural dalam penelitian ini adalah komik edukatif dengan materi tentang dampak pacaran pada remaja yang dikemas kedalam bentuk cerita komik.

\section{Prosedur Pengembangan}

Prosedur yang dipakai dalam penelitian pengembangan komik edukatif tentang dampak pacaran pada remaja bagi siswa SMP menggunakan stretegi pengembangan Sugiyono yang mengimplementasikan prosedur dari Brog and Gall (2008, hlm. 298) yaitu : “1) potensi dan masalah, 2) pengumpulan data, 3) desain produk, 4) validasi desain, 5) revisi desain, 6) uji coba produk, 7) revisi produk, 8) uji coba pemakaian, 9) revisi produk, 10) produksi masal", Adapun penjelasan dengan bagan, terkait dengan penelitian pengembangan media komik edukatif tentang dampak pacaran pada remaja sebagai berikut:

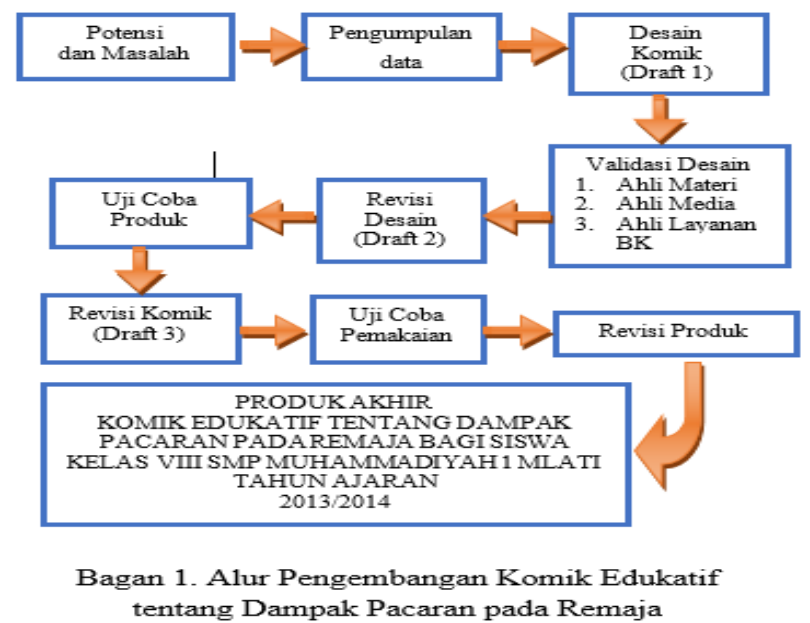




\section{Subjek Penelitian}

Suharsimi (2010, hlm. 188) mengatakan subjek penelitian adalah subjek yang dituju untuk diteliti oleh peneliti. Terkait dengan penelitian pengembangan ini, subjek penelitian dalam uji coba produk komik edukatif tentang dampak pacaran pada remaja yaitu siswa kelas VIII SMP Muhammadiyah 1 Mlati dalam uji coba produk dan uji coba pemakaian.

\section{Tempat dan Waktu Pengembangan}

Penelitian pengembangan ini akan dilakukan di SMP Muhammadiyah 1 Mlati yang berlokasi di Jl Magelang Km 7,5 Mlati Sleman. Pemilihan lokasi tersebut disesuaikan dengan tujuan pengembangan yang akan peniliti lakukan yaitu untuk mengembangkan media komik edukatif untuk layanan Bimbingan dan Konseling bidang pribadi sosial. Waktu pengembangan yaitu pada awal semester ganjil tahun ajaran 2013/2014.

\section{Uji Coba Produk}

\section{Uji Coba Desain}

Uji coba desain produk dalam penelitian pengembangan ini berupa draft Komik edukatif. Desain tersebut merupakan contoh dari produk berupa karakter dan tokoh komik yang masih dalam tahap penyelesaian dan harus melalui beberapa tahap yaitu uji validasi dan uji coba. Desain tersebut kemudian akan direvisi dan dikembangkan lebih matang lagi atas pertimbangan dari hasil uji validasi media, materi dan layanan BK yang dilakukan oleh para ahli. Penelitian pengembangan komik edukatif tentang dampak pacaran pada remaja diperlukan validasi oleh ahli, untuk dapat mengetahui kelayakan suatu produk dengan menilai kelemahan dan kelebihan dari suatu produk. Uji validasi produk yang akan dilakukan meliputi:

a. Uji Validasi Materi

Uji validasi materi dilakukan oleh ahli materi, yaitu adalah individu yang mempunyai kompetensi dan kemampuan untuk menilai dalam hal materi, terutama dalam komik ini lebih menekankan pada bidang pribadi sosial. Kualifikasi ahli materi meliputi yaitu lulusan S1 atau S2 yang sesuai dengan bidang keahlian terhadap materi komik tersebut.

b. Uji Validasi Media

Uji validasi media dilakukan oleh ahli media. Ahli media adalah individu yang mempunyai kualifikasi khusus dalam penilaian sebuah media, kualifikasi tersebut meliputi lulusan S1 atau S2 bidang teknologi pendidikan, teknologi pengajaran, pembelajaran, dan pengalaman yang memadai dalam bidang media layanan Bimbingan dan Konseling.

c. Uji Validasi Layanan BK

Uji validasi layanan dilakukan oleh praktisi layanan yang mempunyai kualifikasi khusus dalam penilaian haus mempunyai kualifikasi lulusan S1 atau S2 bimbingan dan konseling yang sesuai dengan ahli di bidang kompetensi, seperti ahli dalam bidang Bimbingan dan Konseling meliputi bidang pribadi, akademik, sosial dan karir. 


\section{Subjek Uji Coba}

Subyek penelitian yang digunakan dalam penelitian pengembangan ini adalah siswa kelas VIII SMP Muhammadiyah 1 Mlati dengan rincian sebagai berikut:

a. Uji Coba Produk

Subyek uji coba produk yang dipakai adalah sebanyak sepuluh siswa, peneliti menggunakan sepuluh siswa berdasarkan acuan dari Sugiono bahwa untuk dapat menguji sebuah produk pada uji coba produk dengan skala terbatas dapat dilakukan dengan 10 karyawan yang mewakili, dalam penelitian pengembangan ini subjek yang diambil yaitu kelas VIII A, B, C, D dengan pemilihan perwakilan dari masingmasing kelas secara acak.

b. Uji Coba Pemakaian

Subyek uji coba pemakaian ini adalah siswa kelas VIII D SMP Muhammadiyah 1 Mlati, dengan pengambilan subyek terdiri dari jumlah satu kelas yaitu 31 siswa yang disesuaikan dengan keadaan sekolah dan berdasarkan rekomendasi guru BK.

3. Jenis Data

Jenis data yang diperoleh dalam pengembangan media komik edukatif tentang dampak pacaran pada remaja berupa data kualitatif dan kuantitatif. Data kualitatif diperoleh dari uji coba validasi ahli, uji coba produk, dan uji coba pemakaian yang berupa masukan, tanggapan, saran dan kritik untuk merevisi dalam proses perbaikan komik edukatif tentang dampak pacaran pada remaja. Data kuantitatif diperoleh dari hasil uji coba validasi ahli, uji coba lapangan utama dan uji coba lapangan operasional yang berupa penilaian secara umum mengenai komik edukatif tentang dampak pacaran pada remaja.

\section{Instrumen Pengumpulan Data}

Instrumen yang digunakan dalam metode pengumpulan data berupa lembar pengamatan dan angket/kuesioner. Ada empat instrumen yang digunakan dalam pengembangan komik edukatif tentang dampak pacaran yaitu:

a. Instrumen pertama adalah lembar evaluasi untuk ahli materi berupa lembar pengamatan, tanggapan atau penilaian ahli terhadap seluruh komponen dan isi materi komik edukatif tentang dampak pacaran pada remaja.

b. Instrumen kedua adalah lembar evaluasi untuk ahli media berupa lembar pengamatan, tanggapan atau penilaian terhadap komik edukatif tentang dampak pacaran bagi siswa kelas VIII SMP Muhammadiyah 1 Mlati.

c. Instrumen ketiga adalah lembar evaluasi untuk ahli layanan Bimbingan dan Konseling berupa lembar pengamatan, tanggapan atau penilaian terhadap efektivitas komik edukatif tentang dampak pacaran jika dijadikan sebagai media dalam layanan Bimbingan dan Konseling, bagi siswa kelas VIII SMP Muhammadiyah 1 Mlati.

d. Instrumen keempat adalah lembar evaluasi yang ditujukkan kepada siswa berupa angket tanggapan atau penilaian terhadap komik edukatif tentang dampak pacaran bagi siswa kelas VIII SMP Muhammadiyah 1 Mlati. 


\section{Teknik Analisis Data}

Teknik analisis data menggunakan analisis isi dan analisis deskriptif.

a. Analisis Isi (data kualitatif)

Dilakukan dengan menganalisis, mengelompokkan informasi-informasi atau data berupa tanggapan, masukan, serta saran dari uji ahli dan saran atau komentar dari siswa, kemudian hasil analisis data kualitatif dijadikan bahan pertimbangan melakukan revisi produk.

b. Analisis Deskriptif (data kuantitatif)

Dilakukan dengan menganalisis data kuantitatif yang diperoleh dari angket pada uji lapangan awal, uji lapangan utama dan uji lapangan operasional. Skala penilaian yang digunakan dalam menentukan kualitas komik edukatif tentang dampak pacaran pada remaja sebagai berikut:

Tabel 1. Skala Penilaian

\begin{tabular}{|l|c|c|}
\hline $\begin{array}{c}\text { Jawaban yang } \\
\text { dipilih }\end{array}$ & $\begin{array}{c}\text { Bobot } \\
\text { penilaian }\end{array}$ & Kategori \\
\hline Pilihan pertama & 4 & Sangat Baik \\
\hline Pilihan kedua & 3 & Baik \\
\hline Pilihan ketiga & 2 & Kurang Baik \\
\hline Pilihan keempat & 1 & Tidak Baik \\
\hline
\end{tabular}

Adapun deskripsi skala penilaian secara lebih rinci sebagai berikut:

1) Kategori sangat baik (SB) meliputi: Sangat mudah dipahami, sangat jelas, sangat menarik, sangat sesuai, sangat baik dan sangat bermanfaat diberi nilai 4 .

2) Kategori baik (B) meliputi: Mudah dipahami, jelas, menarik, sesuai, dan bermanfaat diberi nilai 3 .

3) Kategori kurang baik (KB) meliputi: Kurang mudah dipahami, kurang jelas, kurang menarik, kurang sesuai, kurang baik, dan kurang bermanfaat diberi nilai 2 .

4) Kategori tidak baik (TB) meliputi: Tidak mudah dipahami, tidak jelas, tidak menarik, tidak sesuai, dan tidak bermanfaat diberi nilai 1.

Berikut adalah kisi-kisi yang digunakan untuk penilaian komik edukatif tentang dampak pacaran pada remaja bagi siswa kelas VIII SMP:

Tabel 2

Kisi-Kisi Lembar Pengamatan Penilaian Ahli Materi

Terhadap Kualitas Komik Edukatif tentang Dampak Pacaran Pada Remaja

\begin{tabular}{|l|l|c|}
\hline No & \multicolumn{1}{|c|}{ Unsur-unsur yang dinilai } & $\begin{array}{c}\text { Jumlah } \\
\text { Indikator }\end{array}$ \\
\hline $\mathbf{1}$ & Isi nilai edukatif dalam cerita komik & $\mathbf{3}$ \\
\hline $\mathbf{2}$ & Cakupan isi materi & $\mathbf{5}$ \\
\hline $\mathbf{3}$ & Runtutan materi & $\mathbf{4}$ \\
\hline $\mathbf{4}$ & Kejelasan & $\mathbf{4}$ \\
\hline
\end{tabular}


50 | Laras - Pengembangan Komik Edukatif ...

Tabel 3

Kisi-Kisi Lembar Pengamatan Penilaian Ahli Media

Terhadap Kualitas Komik Edukatif tentang

Dampak Pacaran Pada Remaja

\begin{tabular}{|c|l|c|}
\hline No & \multicolumn{1}{|c|}{ Unsur-unsur yang dinilai } & $\begin{array}{c}\text { Jumlah } \\
\text { Indikator }\end{array}$ \\
\hline $\mathbf{1}$ & $\begin{array}{l}\text { Unsur komik meliputi Kualitas } \\
\text { tampilan Cover }\end{array}$ & $\mathbf{3}$ \\
\hline $\mathbf{2}$ & Kualitas Karakter & $\mathbf{4}$ \\
\hline $\mathbf{3}$ & $\begin{array}{l}\text { Kemampuan Frame dalam membatasi } \\
\text { adegan cerita secara jelas }\end{array}$ & $\mathbf{2}$ \\
\hline $\mathbf{4}$ & $\begin{array}{l}\text { Kualitas penggunaan balon kata } \\
\text { dalam percakapan kata dalam komik }\end{array}$ & $\mathbf{4}$ \\
\hline $\mathbf{5}$ & $\begin{array}{l}\text { Narasi mampu menjelaskan keadaan } \\
\text { tertentu dengan kalimat }\end{array}$ & $\mathbf{2}$ \\
\hline $\mathbf{6}$ & Kejelasan Efek Suara & $\mathbf{1}$ \\
\hline $\mathbf{7}$ & Penempatan Latar Belakang & \multicolumn{2}{|}{} \\
\hline
\end{tabular}

Tabel 4

Kisi-Kisi Lembar Pengamatan Penilaian Ahli Layanan BK

Terhadap Kualitas Komik Edukatif tentang Dampak Pacaran Pada Remaja

\begin{tabular}{|l|l|c|}
\hline No & \multicolumn{1}{|c|}{ Unsur-unsur yang dinilai } & $\begin{array}{c}\text { Jumlah } \\
\text { Indikator }\end{array}$ \\
\hline $\mathbf{1}$ & $\begin{array}{l}\text { Komik sebagai media layanan BK } \\
\text { dilihat dari Efektifitas komik edukatif } \\
\text { dengan layanan BK }\end{array}$ & $\mathbf{6}$ \\
\hline $\mathbf{2}$ & $\begin{array}{l}\text { Materi bimbingan mendukung } \\
\text { pelaksanaan layanan pribadi sosial }\end{array}$ & 7 \\
\hline
\end{tabular}

Tabel 5

Kisi-Kisi Angket Penilaian Siswa Terhadap Kualitas

Komik Edukatif Tentang Dampak Pacaran Pada Remaja|

\begin{tabular}{|l|l|c|}
\hline No & \multicolumn{1}{|c|}{ Unsur-unsur yang dinilai } & $\begin{array}{c}\text { Jumlah } \\
\text { Indikator }\end{array}$ \\
\hline $\mathbf{1}$ & $\begin{array}{l}\text { Aspek tampilan gambar komik (Kualitas } \\
\text { tampilan Cover dan Kualitas Karakter) }\end{array}$ & $\mathbf{4}$ \\
\hline $\mathbf{2}$ & $\begin{array}{l}\text { Aspek materi (Cakupan materi dan } \\
\text { Manfaat komik) }\end{array}$ & $\mathbf{8}$ \\
\hline $\mathbf{3}$ & Aspek Skenario komik (alur cerita) & $\mathbf{3}$ \\
\hline
\end{tabular}

Setelah menjumlahkan dan mengelompokkan masing-masing jawaban kemudian data yang diperolah diubah ke dalam skor bentuk nilai dengan rumus sebagai berikut ini:

Nilai $=\frac{\text { Jumlah skor yang diperoleh }}{\text { Jumlah skor ideal }} \times 100$

Setelah diperoleh data nilai tersebut, kemudian diinterprestasikan ke dalam empat kriteria yang mengacu dari pendapat Suharsimi (2010, hlm. 192) bahwa Jika peneliti ingin mengakategorikan nilai menjadi 4 (empat) kategori, maka tiap-tiap bagian jarak nilainya 25. Yaitu", "nilai SB = Sangat Baik, jika rentangnya 76-100", "nilai B = Baik, jika 
rentangnya 51-75", "nilai $\mathrm{C}=$ Cukup, jika rentangnya 26-50", "nilai $\mathrm{K}=$ Kurang, jika rentangnya kurang dari 26".

\section{HASIL DAN PEMBAHASAN}

Pembahasan hasil penelitian pengembangan komik edukatif tentang dampak pacaran pada remaja disesuaikan dengan prosedur penelitin $\mathrm{RnD}$ dalam yang telah diuji cobakan pada siswa kelas VIII di SMP meliputi:

\section{Potensi dan Masalah}

Pada tahap penelitian awal peneliti mengumpulkan dan menganalisis potensi, masalah, dan kebutuhan siswa mengenai komik edukatif tentang dampak pacaran pada remaja. Untuk mendapatkan informasi dan data yang dibutuhkan, peneliti melakukan pengumpulan data berdasarkan data-data yang diperoleh melalui konseling individu dan dari hasil instrumen Inventori Tugas Perkembangan (ITP) beserta Analisis Tugas Perkembangan (ATP) pada siswa SMP Muhammadiyah 1 Mlati yang telah dilakukan oleh peneliti, membuktikan masih rendah kematangan siswa dalam pergaulan dengan teman lawan jenis, hal ini bisa dibuktikan dengan alasan kedatangan siswa menemui praktikan (sebagai guru BK) yang selalu berkeluh kesah kepada permasalahan pribadi dan sosial terutama masalah pacaran. Hal ini menunjukkan bahwa kesadaran siswa dalam memenuhi tugas perkembangan terkait kematangan dalam pergaulan dengan lawan jenis masih sangat rendah.

Potensi komik edukatif sebagai media layanan Bimbingan dan Konseling belum digali, bahkan, belum ada terutama untuk menyampaikan materi pendidikan mengenai dampak pacaran pada remaja yang terkait dengan layanan Bimbingan dan Konseling bagi siswa SMP. Berdasarkan hasil penelitian awal yang dilakukan melalui observasi di sekolah, data-data yang diperoleh melalui konseling individu dan dari hasil penyebaran instrumen Inventori Tugas Perkembangan (ITP) dapat disimpulkan bahwa perlu adanya sebuah media bimbingan yang disesuaikan dengan kebutuhan siswa yang dapat digunakan oleh guru pembimbing dan siswa sebagai layanan Bimbingan dan Konseling bidang pribadi sosial di sekolah.

\section{Mengumpulkan Informasi}

Berdasarkan analisis potensi dan masalah di atas, peneliti melakukan studi literatur dengan mempelajari literatur-literatur bacaan yang relevan disesuaikan dengan variable penelitian pengembangan ini yaitu mengenai materi dampak pacaran pada remaja dan mengenai komik, peneliti membaca juga contoh komik-komik edukatif dan komik remaja yang ada di pasaran atau toko buku, mempelajari secara teori dan komponen atau unsur-unsur dalam komik.

Hal ini berguna sebagai reverensi dalam mengembangkan cerita, karakter, tokoh komik yang ingin dibuat kedalam komik edukatif dengan materi dampak pacaran pada remaja. Adapun literatur yang berhubungan dengan variable penelitian ini antara lain: 
52 | Laras - Pengembangan Komik Edukatif ...

Tabel 6

Literatur dalam Pengembangan Komik Edukatif

Tentanag Dampak Pacaxan Pada Remaja

\begin{tabular}{|c|c|c|c|}
\hline No & Judul buku/artikel & Pengarang/situs & $\begin{array}{l}\text { Materi yang } \\
\text { Digunakan }\end{array}$ \\
\hline \multirow[t]{2}{*}{1} & $\begin{array}{l}\text { Komik Perubahan Iklim \& } \\
\text { Pemanasan Global }\end{array}$ & \multirow{2}{*}{$\begin{array}{l}\text { Ach. Desmon A } \\
\text { www.ayocerdaska } \\
\text { nbangsa.org }\end{array}$} & \multirow{2}{*}{$\begin{array}{l}\text { Hanya melihat } \\
\text { gambar dan contoh } \\
\text { komik edukatif }\end{array}$} \\
\hline & $\begin{array}{l}\text { Komik Bencana Di Sekitar } \\
\text { Kita }\end{array}$ & & \\
\hline 3 & $\begin{array}{l}\text { Comic Makjing i cara } \\
\text { membuat komik }\end{array}$ & M, S. Gumelar & $\begin{array}{l}\text { Gaya menggambar } \\
\text { dalam komik }\end{array}$ \\
\hline 4 & $\begin{array}{l}\text { Bikin komik dengan adobe } \\
\text { Illustrator \& Adobe } \\
\text { Photoshop }\end{array}$ & Lusia Susiani & $\begin{array}{l}\text { Unsur-unsur dalam. } \\
\text { komik }\end{array}$ \\
\hline 5 & $\begin{array}{l}\text { Ketika Remaja \& Pubertas } \\
\text { Tiba }\end{array}$ & R. Aden. & $\begin{array}{l}\text { Tahap-tahap } \\
\text { pacaran }\end{array}$ \\
\hline 6 & $\begin{array}{l}\text { Pengembangan Materi } \\
\text { Bimbingan dan Konseling } \\
\text { Berbasis Multimedia }\end{array}$ & $\begin{array}{l}\text { Nurbowse Budi } \\
\text { Utoms, dan } \\
\text { Slamet Windarto }\end{array}$ & $\begin{array}{l}\text { Dampak Negatif } \\
\text { Pacaran }\end{array}$ \\
\hline
\end{tabular}

\section{Desain Produk Awal}

Pengembangan produk awal yaitu membuat skenario alur cerita dan, membuat karakter tokoh dalam komik, menyusun materi edukatif tentang dampak pacaran yang dikemas kedalam bentuk cerita dan dijadikan sebagai desain komik (Draft 1).
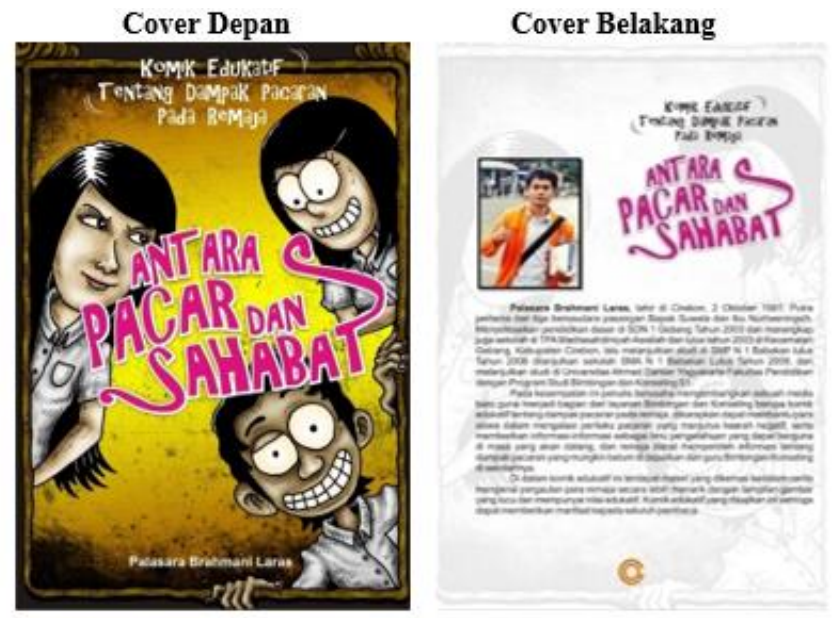

Gambar 1. Tampilan Cover Komik Edukatif Draft 1

\section{Validasi Desain (Draft 1)}

Validasi desain merupakan kegiatan penilaian dan evaluasi yang dilakukan oleh beberapa ahli terhadap komik edukatif tentang dampak pacaran pada remaja yang masih berupa (Draft 1). Beberapa ahli yang dimaksud adalah ahli materi, ahli media, dan ahli layanan Bimbingan dan Konseling yang berperan melakukan penilaian dan evaluasi terhadap pengembangan produk komik edukatif tentang dampak pacaran pada remaja (Draf 1), adapun hasil dari penilaian validasi desain oleh ahli sebagai berikut:

\section{a. Uji Ahli Materi}

Penilaian dan evaluasi komik edukatif tentang dampak pacaran pada remaja dilakukan oleh Dra. Alif Muarifah, S.Psi., M.Si. yang merupakan salah satu dosen Bimbingan dan Konseling UAD yang berkompeten dalam bidang materi dengan kualifikasi pendidikan S1 Psikologi, dan S2 Psikologi. 


\section{Komentar dan Saran}

Menurut ahli materi percakapan dalam komik diusahakan tidak menimbulkan anjuran seperti dalam percakapan antara Dimas dengan Beni yang membicarakan tips ciuman seperti yang terdapat pada gambar hal 17. Untuk pengembangan Tingkat S1 media komik edukatif tentang dampak pacaran pada remaja ini, sudah terbilang baik, hanya sajah perlu diperhatikan kata-kata dan lebih disesuaikan lagi tujuan yang ingin dicapai dengan isi materi.

Berdasarkan hasil penilaian komik edukatif tentang dampak pacaran pada remaja yang dilakukan oleh ahli materi diketahui bahwa nilai yang diperoleh adalah $78,12 \%$ dengan kategori "sangat baik". Sehingga secara keseluruhan, ahli materi memberikan pernyataan layak untuk diuji cobakan pada uji coba produk lapangan utama tanpa revisi.

\section{b. Uji Ahli Media}

Penilaian dan evaluasi komik edukatif tentang dampak pacaran pada remaja dilakukan oleh Drs. Said Alhadi, M.Pd. dengan kualifikasi S1 dan S2 Pendidikan yang mempunyai keahlian pada bidang Teknologi Pembelajaran, sehingga sesuai untuk melakukan penilaian dan evaluasi terhadap komik edukatif tentang dampak pacaran pada remaja sebagai media dalam Bimbingan dan Konseling.

\section{Komentar dan saran}

Setelah melalui proses penilaian dan konsultasi dengan ahli media, maka ada beberapa perbaikan pada komik edukatif ini meliputi: setting cerita komik sudah bagus hanya saja perlu diperhatikan mengenai tentang ukuran kertas terlalu besar jika bisa lebih di perkecil lagi. Penjilidan komik edukatif ini haus lebih diperkuat lagi menggunakan spiral hanya sebagian sehingga menjadi tidak kuat.

Berdasarkan hasil penilaian komik edukatif tentang dampak pacaran pada remaja yang dilakukan oleh ahli media diketahui bahwa nilai yang diperoleh adalah 91,18\% dengan kategori "sangat baik", sehingga secara keseluruhan komik edukatif tentang dampak pacaran pada remaja layak untuk uji coba lapangan dengan revisi. Sehingga komik edukatif hasil dari perbaikan tersebut menjadi komik edukatif (Draft 2) yang siap untuk di uji coba dan digunakan di lapangan.

\section{c. Uji ahli layanan Bimbingan dan Konseling}

Penilaian dan evaluasi komik edukatif tentang dampak pacaran pada remaja dilakukan oleh Mencik Rumiasih, S.Pd. dengan kualifikasi S1 Bimbingan dan konseling yang mempunyai keahlian pada bidang praktisi layanan BK, sehingga sesuai untuk melakukan penilaian dan evaluasi terhadap komik edukatif tentang dampak pacaran pada remaja sebagai media dalam layanan Bimbingan dan Konseling.

\section{Komentar dan saran}

Setelah melalui proses penilaian serta konsultasi dengan ahli layanan BK, maka ada beberapa revisi pada komik edukatif meliputi: komik edukatif tentang dampak pacaran pada remaja dengan judul antara pacar dan sahabat, dapat digunakan sebagai 
media layanan kreatif, edukatif dan dapat meningkatkan peserta didik untuk lebih tertarik terhadap layanan Bimbingan dan Konseling.

Berdasarkan tabel penilaian komik edukatif tentang dampak pacaran pada remaja yang dilakukan oleh ahli layanan BK diketahui bahwa nilai yang diperoleh adalah 94,23\% dengan kategori "sangat baik". Namun dari ahli layanan BK merekomendasikan peneliti untuk melakukan revisi komiknya setelah itu draf komik yang sudah diperbaiki dinilai kembali mendapat nilai 100\%. Sehingga secara keseluruhan komik edukatif tentang dampak pacaran pada remaja dengan judul antara pacar dan sahabat, dapat digunakan sebagai media layanan kreatif, edukatif dan dapat meningkatkan peserta didik untuk lebih tertarik terhadap layanan Bimbingan dan Konseling.

\section{Revisi Desain Komik (Draf 1)}

Setelah melewati uji validasi desain komik edukatif tentang dampak pacaran pada remaja direvisi sesuai dengan saran dari para ahli. Hasil revisi tersebut sebagai bahan untuk desan komik (Draft 2) yang siap untuk di uji coba produk dan digunakan di uji coba pemakaian (lapangan oprasional).

\section{Uji Coba Produk (Lapangan Utama)}

Uji coba produk pada lapangan utama yang dilakukan setelah merevisi komik edukatif tentang dampak pacaran pada remaja berdasarkan saran dan komentar dari para ahli dalam validasi desain. Selanjutnya dilakukan uji coba produk yang bertujuan sebagai uji keterbacaan komik edukatif melalui penilaian siswa SMP Muhammadiyah 1 Mlati Kelas VIII A, B, C, D yang diambil secara acak dengan jumlah 10 siswa.

Berdasarkan hasil penilaian komik edukatif tentang dampak pacaran pada remaja secara keseluruhan mempunyai nilai $86,67 \%$ termasuk dalam kategori sangat baik, karena berada pada rentang nilai 75-100.

\section{Komentar dan Saran}

Sebagian besar subjek uji coba lapangan utama berkomentar positif dan mendukung komik edukatif tentang dampak pacaran pada remaja ini yang dapat dijadikan sumber informasi, dan menambah pengetahuan tentang dampak pacaran pada remaja. Adapun saran dari salah satu subjek adalah warna tampilan komik kurang menarik, Gambar komik ada yang jelas dan kurang jelas, namun komik sudah sangat menarik, sudah bagus karena dapat mengetahui dampak negatif saat berpacaran, dan bisa mengambil sisi positifnya, dan mampu menginspirasi anak-anak remaja.

\section{Revisi Produk (Komik Draf 2)}

Berdasarkan hasil penilaian uji coba produk (lapangan utama) terhadap komik edukatif tentang dampak pacaran pada remaja, terdapat beberapa revisi dan saran, hasil dari perbaikan tersebut menjadi komik edukatif (Draft 3) yang siap untuk di uji coba pemakaian pada lapangan operasional.

\section{Uji Coba Pemakaian (Lapangan Operasional)}

Berdasarkan hasil penilaian komik edukatif tentang dampak pacaran pada remaja secara keseluruhan yang dilakukan pada uji coba lapangan operasional diketahui nilai 
yang diperoleh adalah $89,35 \%$ termasuk dalam kategori sangat baik, karena berada pada rentang nilai $75-100$.

\section{Komentar dan Saran}

Sebagian besar subjek uji coba produk lapangan utama berkomentar positif dan mendukung komik edukatif tentang dampak pacaran pada remaja ini yang dapat dijadikan sumber informasi, dan menambah pengetahuan tentang dampak pacaran pada remaja, saran dan komentar sebagian besar subjek uji coba menganggap komik sangat menarik, lucu, kreatif dan mudah untuk dibaca, mampu menjadi informasi buat anakanak remaja, banyak siswa yang ingin memiliki komik edukatif ini, karena komik edukatif ini sangat bagus dan cerita menarik untuk dibaca, namun hanya sajah pada aspek tampilan warna harus dibuat semenarik mungkin sehingga siswa lebih tertarik dalam membaca komik edukatif tersebut.

\section{Revisi Produk}

Berdasarkan hasil penilaian dan evaluasi setelah validasi ahli dan uji coba lapangan utama terhadap komik edukatif tentang dampak pacaran pada remaja, adabeberapa bagian dari komik yang perlu direvisi sesuai dengan komentar dan saran yangdidapatkan. Revisi pada beberapa bagian tertentu dilakukan hanya berdasarkan saran-saran yang diperoleh dari hasil validasi desain oleh ahli materi, ahli media, dan ahli layanan BK

\section{Analisis Kajian Produk Akhir}

Berdasarkan hasil penilaian pada tahap validasi ahli (uji ahli),uji coba produk pada lapangan utama, dan uji coba pemakaian pada lapangan operasional, maka produkakhir yang dihasilkan berupa komik edukatif tentang dampak pacaran pada remaja yang telah diuji cobakan pada siswakelas VIII SMP Muhammadiyah 1 Mlati dinyatakan layak dengan kategori "sangat baik" dan dapatdigunakan oleh guru pembimbing untuk dijadikan sebagai media dalam memberikan layanan bimbingan,serta dapat digunakan oleh siswa untuk mendapatkan informasi dampak pacaran pada remaja. Adapun hasil penilaian dari komik edukatif tentang dampak pacaran pada remaja secara keseluruhan sebagai berikut:

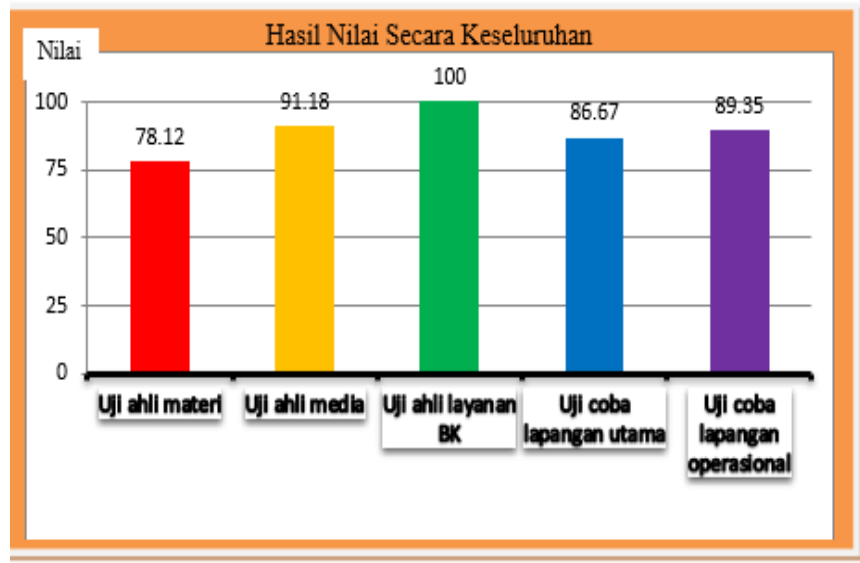

Diagram 1. Perolehan Nilai Komik Edukatif Secara Keseluruhan 
Berdasarkan hasil perhitungan kualitas komik secara keseluruhan mendapatkan nilai 89,06, Karena nilai dari 5 aspek tersebut berada pada rentang nilai 76 - 100 maka Komik edukatif tentang dampak Pacaran pada remaja dilihat secara materi, media, dan layanan Bimbingan dan Konseling, uji coba produk, uji pemakaian termasuk dalam kategori "Sangat Baik".

\section{SIMPULAN}

Berdasarkan hasil penelitian pengembangan komik edukatif layak untuk digunakan oleh guru pembimbing dalam memberikan layanan bimbingan di sekolah, serta bagi siswa dapat dijadikan bahan bacaan yang informatif yang bisa digunakan secara mandiri. Komik ini secara keseluruhan dapat diterima oleh siswa sebagai remaja karena tampilan menarik dan cerita yang mampu menginspirasi para remaja dalam bertindak secara positif, siswa merasa tertarik, berminat dan antusias dalam membaca komik edukatif ini, komik ini juga dapat meningkatkan pemahaman peserta didik terkait dengan materi dampak pacaran, hal ini dibuktikan dengan siswa mengisi dan menjawab lebar evaluasi yang membahas seputar materi sesuai pemahaman yang siswa dapat ketika membaca komik edukatif ini, dan komik dapat menjadi media yang efektif dan efisien dalam menjelaskan materi tentang dampak pacaran pada remaja.

\section{DAFTAR PUSTAKA}

Aden, R. (2010). Ketika Remaja \& Pubertas Tiba. Yogyakarta: Hanggar Kreator.

Al-Adawiyyah, Robiah \& Syamsuddin, Hatta. (2010). Pacaran? Ih Gak Banget. Surakarta: Afra Publishing.

Ali, Mohammad \& Asrori. (2009). Psikologi Remaja Perkembangan Peserta Didik. Jakarta: PT Bumi Aksara.

Alwisol. (2005). Psikologi Kepribadian. Malang: UMM Press.

Asmani, Ma'mur J. (2010). Panduan Efektif Bimbingan dan Konseling di Sekolah. Yogyakarta: Diva Press.

Buku Biru.

(2012). Kiat Mengatasi Kenalakan Remaja di Sekolah. Yogyakarta:

Azhar, Arsyad. (2011). Media Pengembangan, Jakarta: Raja Grafindo Persada.

Daryanto. (2011). Media Pembelajaran. Bandung: PT Sarana Tutorial Nurani Sejahtera.

Eka Dewi, Heriana. (2012). Memahami Perkembangan Fisik Remaja. Yogyakarta: Gosyen Publishing. 
Elis, Mediawati. (2011). Pembelajaran Akuntansi Keuangan Melalui Media Komik Untuk Meningkatkan Prestasi Mahasiswa. Jurnal Penelitian Pendidikan Vol. 12 No. 1.

Gantina, Eka, dan Karsih. (2011). Assesmen Teknik Non Tes dalam BK Komprehensif. Jakarta: Indeks.

Gumelar, M, S. (2011). Comic Making: Cara Membuat Komik. Jakarta: Indeks.

Gunarsa, Singgih D \& Gunarsa, Yulia Singgih. (2012). Psikologi Untuk Muda Mudi. Jakarta: Libri.

Farida, H, Dkk. (2009). Pengembangan Komik Edukasi sebagai Media Bimbingan Pribadi Sosial untuk Meningkatkan Efikasi Diri Siswa SMA terhadap Perilaku Seksual Beresiko. Laporan Penelitian. Yoygakarta: UNY.

Harianjogja.com. (2013). Pacaran di Toilet dua Pelajar SMP Bermesraan di toilet Sekolah. Diakses dari http://www.harianjogja.com/baca/2013/08/05/pacaran-ditoilet-dua-pelajar-smp-bermesraan -di-toilet-sekolah 435164(diakses pada hari Jumat tanggal 16 Agustus 2013 pukul 13:08 WIB).

Hikmawati, F. (2011). Bimbingan dan Konseling edisi Revisi. Jakarta: Rajawali Press.

Khusnul Aini \& Asep Sufyan Ramadhy. (2011). Hamil di luar Nikah Usia Usia Remaja. dikutip dari (http://cybervecto.blogspot.com/2011/04/hamil-di-luar-nikah-usiaremaja.html) diakses pada hari Senin tanggal 19 Agustus 2013 Pukul 0: 48 WIB.

Kompas.com. (2010). Wah Gaya Berpacaran Remaja Kian Bebas. Diakses darihttp://regional.kompas.com/read/2010/02/14/15415059/Wah.Gaya.Berpacan.Re maja.Kian.Bebas(diakses pada hari Jumat tanggal 22 Maret 2013 pukul 15:29 WIB).

Lestari, Suci Dkk. (2009). Media Grafis Media Komik. Malakah. Bandung: Universitas Pendidikan Indonesia.

Markus. (2012). Survey Perilaku Seks di Sintang:60 Persen ABG Lakukan Aborsi. Tribunne. Diakses dari http://theglobe journal.com/kesehatan/survey-peri laku-seks-60-persen-abg-lakukan-aborsi/index.php. (Diakses Pada Tanggal 21 Maret 2013 pukul 21.55 WIB).

Muhyidin, Muhammad. (2005). Remaja Miskin Dilarang Pacaran. Yogyakarta: Binar Press.

Mulya. (2013). Dampak Positif Pacaran. Diakses dari http://mulyasetyas.wordpress.com/201 0/09/21/(Diakses pada tanggal 14/05/2013 pukul WIB 10:32).

Monks, Knoers \& Haditomo, Siti Rahayu. (2002). Psikologi Perkembangan Pengantar Dalam Berbagai Bagiannya. Yogyakarta: Gajah Mada University PRESS. 
Nana Syaodih, Sukmadinata. (2007). Bimbingan dan Konseling dalam Praktek. Bandung: Maestro. . (2010). Metode Penelitian Pendidikan. Bandung: Rosda.

Nurbowo, Budi Utomo \& Slamet Windarto. 2011. Pengembanngan Materi Bimbingan dan Konseling Berbasis Multimedia. Yogyakarta: Paramitra Publishing.

Nursalim, Mochamad. (2010). Media Bimbingan dan Konseling. Surabaya: Sinar University Press.

Puslitjaknov. (2008). Metode Penelitian Pengembangan.

Sadiman, DKK. (2011). Media Pendidikan Pengertian, Pengembangan, dan Pemanfaatannya. Jakarta: Rajawali Press.

Setiawan, R \& Nurhidayah, S. (2008). Pengaruh Pacaran Terhadap Perilaku Seks Pranikah. Journal Soul. Vol. 1, No 2. September 2008.

Solopos. (2012). Bunuh Mantan Pacar Siswa SMP diganjar 6 Tahun Penjara. Diakses dari http://www.solopos.com/2012/05/04/bunuh-mantan-pacar-waduh-siswa-smpdiganjar-6-tahun-penjara-183196(Diakses pada hari Rabu tanggal 15 Agustus 2013 pukul 7:32 WIB).

Suharsimi, Arikunto. (2009). Manajemen Penelitian. Jakarta : Rineka Cipta. . (2010). Prosedur Penelitian Suatu Pendekatan Praktik. Jakarta : Rineka Cipta. . (2010). Penelitian Tindakan. Yogyakarta: Aditya Media. . (2011). Penilaian \& Penelitian Bidang Bimbingan dan Konseling. Yogyakarta : Aditya Media.

Sugiono. (2008). Metode Penelitian Kuantitatif Kualitatif dan R\&D. Bandung: Alfabeta. . (2009). Metode Penelitian Pendidikan Pendekatan Kuantitatif, Kualitatif, dan R\&D. Bandung : Alfabeta.

. (2012). Metode Penelitian Pendidikan Pendekatan Kuantitatif, Kualitatif, dan R\&D. Bandung : Alfabeta.

Sujana, Nana \& Rivai, Ahmad. (2010). Media Pengajaran. Bandung: Sinar Baru Algensindo.

Sukiman. (2012). Pengembangan Media Pembelajaran.Yogyakarta: Pedagogia. 
Supriatna, Mamat. (2011). Bimbingan dan Konseling Berbasis Kompetensi Orientasi Dasar Pengembangan Profesi Konselor. Jakarta: Rajawali Press.

Susiani, Lusia. (2006). Bikin Komik dengan Adobe Illustrator \& Adobe Photoshop.Yogyakarta: CV ANDI.

Tempo.com. (2012). Pacaran Pertama anak Indonesia Umur 12 Tahun. Diakses dari http://www.tempo.co/read/news/2012/06/06/174408718/KPAIPacaran-PertamaAnak-Indonesia-Umur-12-Tahun(Diakses pada tanggal 14 Maret 2013 Pukul 11.41 WIB).

Waluyanto, Dwi H. (2005). Komik Sebagai Media Komunikasi Visual Pembelajaran. Jurnal Nirmana, Vol. 7, No.1.P. 45-55. Januari. Diakses dari (http://www.petra.ac.id/puslit/journals/dir.php?DepartemenID=DKV).

Willis, Sofyan S. (2012). Remaja dan Masalahnya Mengupas Berbagai Bentuk Kenakalan Remaja Narkoba, Free Sex dan Pemecahannya. Bandung: Alfabeta.

Yamin, Martinis, \& Ansari, Bansu I. (2012). Taktik Mengembangkan Kemampuan Individual Siswa. Jakarta: Referensi.

Yusuf, Syamsu \& Nurihsan, J. (2009). Landasan Bimbingan dan Konseling. Bandung: Rosda.

Yusuf, Syamsu. (2009). Program Bimbingan dan Konseling di Sekolah. Bandung: Rizqi. 
60 | Laras - Pengembangan Komik Edukatif ... 